Ilmenau University of Technology

Institute of Economics

Ilmenau Economics Discussion Papers, Vol. 24, No. 117

\title{
Competition Policy Reform in Europe and Germany - Institutional Change in the Light of Digitization
}

Oliver Budzinski \& Annika Stöhr

November 2018

Institute of Economics

Ehrenbergstraße 29

Ernst-Abbe-Zentrum

D-98 684 Ilmenau

Phone 03677/69-4030/-4032

Fax 03677/69-4203

http://www.wirtschaft.tu-ilmenau.de

ISSN 0949-3859 


\title{
Competition Policy Reform in Europe and Germany - Institutional Change in the Light of Digitization
}

\section{Oliver Budzinski\# \& Annika Stöhr ${ }^{*}$}

\begin{abstract}
The ubiquitous process of digitization changes economic competition on markets in several ways and leads to the emergence of new business models. The increasing roles of digital platforms as well as data-driven markets represent two relevant examples. These developments challenge competition policy, which must consider the special economic characteristics of digital goods and markets. In Germany, national competition law was amended in 2017 in order to accommodate for digitization-driven changes in the economy and plans for further changes are already discussed. We review this institutional change from an economics perspective and argue that most of the reform's elements point into the right direction. However, some upcoming challenges may have been overlooked so far. Furthermore, we discuss whether European competition policy should follow the paragon of the German reform and amend its institutional framework accordingly. We find scope for reform particularly regarding data-driven markets, whereas platform economics appear to be already well-established.
\end{abstract}

Keywords: competition policy, antitrust, industrial economics, digitization, media economics, institutional economics, industrial organization, big data, algorithms, platform economics, two-sided markets, personalized data, privacy, internet economics, consumer protection

JEL-Codes: L40, K21, L86, L82, L81, L10, L15, D80

\# Professor of Economic Theory, Institute of Economics, Institute of Media and Mobile Communication, Ilmenau University of Technology, Germany, Email: oliver.budzinski@tu-ilmenau.de.

M.Sc., Institute of Economics, Ilmenau University of Technology, Germany, Email: annika.stoehr@tu-ilmenau.de.

+ We like to thank Frédéric Marty, Andreas Polk as well as the participants of the conference "Institutional Change through Digitization" (Hamburg, September 2018) for valuable comments on an earlier version of the paper. 


\section{Introduction}

New developments in the economy pose new challenges to competition policy, which is why it represents an area where institutions are subject to comparatively frequent change. This includes particularly more informal institutions like, for instance, standard practices of market delineation, market power assessment, or merger control procedures as well as guidelines. However, notwithstanding, even codified law is amended quite regularly. For instance, just in 2017 Germany's Law against Restrictive Practices (Gesetz gegen Wettbewerbsbeschränkungen, GWB) went through its $9^{\text {th }}$ amendment since its implementation in 1958 (with a $10^{\text {th }}$ amendment being already in discussion).

The overarching economic development that fueled the recent amendment was the ubiquitous process of digitization. In this process, technology lowers the costs of storing, sharing, and analyzing data and by that, changes how consumers behave, how industrial activity is organized, and eventually how authorities need to operate. In terms of the protection of market competition, which is the primary goal of competition policy, the emergence of giant online platforms and their business models based upon platform effects and the sophisticated employment of personalized user data drives modern challenges for competition authorities. Consequently, the recent $9^{\text {th }}$ amendment of German competition law was specifically and explicitly targeted at this development, aiming at making German competition policy fit for the digital age. Institutional change provides the precondition for the competent competition authority - the Federal Cartel Office of Germany (FCO; Bundeskartellamt) - to adequately tackle anticompetitive arrangements and strategies involving digital goods (commodities, contents, services, rights, etc.). Insofar the process of digitization changes the way companies compete with each other, competition rules and their enforcement must reflect these changes.

In this paper, we review the $20179^{\text {th }}$ amendment of German competition law from an economics perspective and assess whether it fits to the economic peculiarities of digital business models. Furthermore, we analyze whether the geographically next higher level of competition policy - the European Union's (EU) competition policy enforced by the European Commission (EC) - should follow the paragon of Germany 
and reform its competition institutions accordingly. We argue that the insights of (digital) platform economics can and are already employed without considerable institutional change on the European level, whereas the characteristics of data-driven competition require changes along the lines of the German reform on the European level as well. Eventually, we point to some additional challenges that the German reform does not fully capture.

\section{What Challenges Does Digitization Pose to the Current Competition Insti- tutions?}

\subsection{The Economics of Digital Platforms}

When a market meets the following three conditions, it can be seen as a platform market (two-sided or multi-sided platform) in the sense of modern industrial economics (Evans \& Schmalensee 2007):

- there are at least two distinct demand groups,

- which are connected via indirect network externalities, and

- transaction costs prevent these demand groups from coordinating themselves directly.

Especially many digital markets meet these conditions; therefore, it is relevant to take a closer look into the economics of platforms to understand the basic economic concepts of these markets. The classic example to illustrate two-sided platforms is the market for payment cards (inter alia, Rochet \& Tirole 2002, 2003, 2006; Caillaud \& Jullien 2003; Armstrong 2006). A provider of a credit card faces both the demand group of customers, who use the credit card as a means of payment, and the distinct group of merchants, who accept the credit card in their shops. The platform operator (here: the credit card provider) faces a so-called chicken-and-egg-problem by having to get both sides "on board", i.e. simultaneously attracting high participation from each distinct customer group. By managing this problem and raising the number of participants on both sides, the platform operator induces two effects and, with that, enhances welfare for all market sides. Firstly, bidirectional indirect positive network effects occur where it is mutually beneficial for both demand groups if the number 
of participants on the other side is increasing. These indirect network effects are essential determinants of platforms. Secondly, the otherwise significant transaction costs of coordinating customers and merchants are reduced. It becomes more efficient for the two groups to interact because the platform internalizes a connection between them. Otherwise, the transaction would be more expensive or not even possible at all.

Coming back to digital markets, the above emphasized mutually positive indirect network effects can be found, for instance, on internet platforms like Ebay, Airbnb, Uber and various hotel-booking platforms (Haucap \& Stühmeier 2016). There are also cases where network effects only occur in one direction. In advertising-financed media, for instance, there is a positive indirect network effect from the group of viewers or users on the group of advertisers: the more viewers or users a media provider has, the higher the benefit for companies that place their ads. However, this correlation does not exist necessarily the other way round: whether more advertising represents a positive effect for viewers is ambivalent at best. In many cases, there can even be a negative indirect network externality where viewers feel disturbed and annoyed by advertisements (Anderson \& Gabszewicz 2006). Besides, there are often also direct network effects, which occur if users of a network service benefit directly from a higher number of other users within the same demand group (inter alia, Farrel/ \& Saloner 1985; Katz \& Shapiro 1985). Examples for this effect can be found in most communication networks: classic communication via telephone, online communication via social networks such as Facebook, or communication services like WhatsApp or Skype (Haucap \& Stühmeier 2016). However, these types of network effects create some particularities with respect to competition policy. Associated with the demandsided economies of scale through the platform, indirect network effects foster concentration tendencies all the way to narrow oligopolies, dominant platforms or even platform monopolies. While the latter may be more allocatively efficient than monopolies in "ordinary" markets, i.e. providing a higher quantity than an "ordinary" monopolist does, they still create scope for market power-based anticompetitive market conduct (abuse of market power) and may yield considerable dynamic inefficiencies. 
Since competition remains the desirable market structure, the sustainability of competition among platforms (in contrast to the emergence of dominant or monopolistic platforms) becomes very important even though platform markets will rather be (narrow) oligopolistic competition (instead of fragmented or atomistic competition). According to recent insights from economic theory, sustainable platform competition is the more likely (Evans \& Schmalensee 2007; Farrell \& Klemperer 2007; Haucap \& Heimeshoff 2014; Haucap \& Stühmeier 2016):

- the weaker and/or the more asymmetric indirect network externalities are,

- the weaker direct network effects are,

- the lower economies of scale are (low importance of fixed cost digression),

- the more user groups operate multi-homing (using more than one platform regularly),

- the higher the market volume is,

- the more heterogeneous the market is, i.e. the more heterogeneous user preferences and goods (products, services, content) are,

- the higher compatibility between different platforms is,

- the stronger innovation dynamics in the market are,

- the lower technical and behavioral economic switching costs are.

The more the opposite of all these factors characterize a platform, the more likely is a tendency towards dominance or monopoly (sometimes called tipping). It is unlikely that this list of factors is already complete; it will rather probably be supplemented by ongoing and future research.

Usually, transaction platforms are distinguished from non-transaction platforms ( $A f$ feldt et al. 2013; Filistrucchi et al. 2013a; Damme et al. 2010; Filistrucchi 2008). In the first case, transactions are directly concluded via the platform or are at least directly observable by it (as, for instance, in the case of Ebay). In the second case, this is not possible. Looking at the example of an internet platform, bringing together the group of users and the group of advertisers, transactions between these two 
groups could emerge but are not concluded through the platform or even observable by the platform operator. ${ }^{1}$

Another classification differentiates natural platform markets, where the platform is necessary for the coordination of the demand groups (prohibitive transaction costs), from artificial platforms, in which an "ordinary" market is deliberately re-organized as a platform to increase profits (of the platform operator). An example for the latter kind of platform would be Amazon, whose original core business was online retailing, i.e. purchasing goods from producers for resale (classic vertical supply chain). However, Amazon later re-organized parts of its business as a two-sided platform (Amazon Marketplace): former upstream sellers/vendors, from whom Amazon purchased goods, now became customers of Amazon's platform marketplace leasing virtual salesroom on the platform in order to offer their products directly to consumers. With that, Amazon has gone from an online retailer to an online shopping mall, focusing on bringing suppliers and buyers together and providing transaction supporting services. Today Amazon operates both business models and, depending on current profitability, shifts goods from Retail to Marketplace and back.

A relevant antitrust implication relates to the problem of economic dependence. Platforms may become a gatekeeper to online transactions, i.e. that sellers must be present on these platforms in order to reach their customers. For instance, it may be indispensable for the business of certain sellers or shops to be present on Amazon Marketplace or to be findable through Google Search; otherwise, significant parts of their market may be foreclosed for them. Incentives for a platform to engage in foreclosure activities surface particularly in the case of vertical integration, i.e. if platforms perform a dual role as platform service and content provider. For instance, if the organizer of a digital marketplace (platform) also acts as a shop operator (user of the platform on the side of "sellers/shops") or providers of ranking services (search services as well as recommendation services) also rank their subsidiaries' businesses in comparison to their competitors, they experience incentives to favour their own contents and services at the expense of competitors. In such cases, market power

However, data-based payment systems such as "pay-per-transaction" partially break this line of reasoning. 
towards vertically related (upstream or downstream) companies may surface already way below traditional market power positions and the superior bargaining power of the gatekeeper platforms may allow for exploitative abuses towards (upstream or downstream) economic-dependent firms (Baye \& Morgan 2001; Bougette et al. 2017; Dinerstein et al. 2018).

Some more particularities need to be taken into account in terms of market delineation, the determination of market power and the competitive assessment of entrepreneurial strategies.

Regarding the pricing, a platform operator has not just to choose a single price for the supplied service or good but must develop a complete pricing structure (Rochet \& Tirole 2003). Overall, the platform subsidizes the platform side from which the higher indirect network effects emanate by an increased price for the platform side with lower indirect network effects. Thus, profit-maximizing platforms apply asymmetric pricing, which internalizes the indirect network effects. Examples for advertising-financed platforms with asymmetric pricing structures are social network services (like Facebook), search engine services (like Google), recommendation services (like Amazon), editorial content sites (like online newspapers), or audio-visual content platforms (like YouTube or Spotify). ${ }^{2}$ Another, reverse, pricing strategy is often observed in computer-based industries. Here, the platform vendors get most of their profits from the consumers of electronic devices (like smartphones or gaming consoles) instead of charging high fees from the app or hardware developers (Evans et al. 2004). In both cases, it can be profit- and welfare-maximizing to set optimal prices for one demand side below marginal costs and subsidize this side by setting the price for the other demand group above marginal costs (Rochet \& Tirole 2003). This asymmetric pricing structure is efficient, so that neither pricing one of the demand groups below marginal costs necessarily constitutes an anticompetitive foreclosure strategy, nor the pricing of the other demand group above marginal costs necessarily implies an abuse of market power.

2 This is not a purely online phenomenon; for example, some local newspapers are distributed to households free of charge, financed by advertising. 
Traditionally, market delineation often starts with the so-called SSNIP-test ("Small but Significant Non-Transitory Increase in Price"), where it is examined if a firm (hypothetically) is in the position to profitably (and not only temporarily) raise its price by 5-10 per cent above the competitive price level. The price increase would be called unprofitable, if consumers see sufficient substitutes for the good and switch to them. In this case, there would have to be more companies or products in the relevant market that have to be considered for the market definition. However, the interrelation of the platform sides and peculiar pricing structures make it difficult to use the SSNIP test for market delineation in platform markets (inter alia, Evans \& Noe/2005, 2008; Evans 2009; Argentesi \& Filistrucchi 2007; Filistrucchi et al. 2013b). The internalized indirect network effects between the different demand groups cause the problem that, in order to evaluate the profitability of a potential price increase on one market side, the reactions on the other market side need to be taken into account (so-called feedback effects). That starts with the decision on which price increase (on which market side) should be computed higher and whether if just one price should be increased or all prices simultaneously (Evans 2003; Haucap \& Stühmeier 2016). A possible price increase on one market side could also lead to negative user reactions on the other market side and, therefore, an overall negative outcome for the platform operator. To avoid the described problems, a few papers discuss possible ideas to apply the SSNIP-test to platform markets (inter alia, Evans \& Noel 2005; Argentesi \& Filistrucchi 2007; Filistrucchi et al. 2013b) for example by taking different elasticities or the changes in profits on both market sides into account. All these possible concepts require a high quality of data and estimation techniques, creating strong practical limits to the application of these concepts.

\subsection{The Economics of Personalized Data and Privacy}

The economics of personalized data (or sometimes economics of privacy) is another area that has a bigger significance on online markets than on "standard" markets (Budzinski 2016). Overall, the commercial employment of information about consumers is advantageous for the strategic choices of suppliers - both on online and offline markets. However, online and offline markets differ in terms of possibilities to collect and analyze individualized (personalized) customer data. Customers are 
usually anonymous on offline markets like classic stores, for instance, if they pay with cash. In order to collect personalized data in such markets, customers must be induced to provide it, for example via discount systems, payment with debit cards, etc. Online, however, customers must identify themselves (at the latest when they pay and with non-digital goods also through the delivery address). In these markets, there are several ways to personalize customer data and to extract individual information (e.g., cookies, IP-identification, personalized accounts, etc.). Next to simple personal data (like names, addresses, payment information, etc.), these devices are particularly suitable to track more sophisticated personal data, for instance, data about individual consumption histories, search patters, and (online) lifestyles. Sophisticated personalized data allows for drawing conclusions about individual preferences of customers including both stated preferences (for instance, through "like"buttons, ratings, comments on goods and suppliers, etc.) as well as revealed preferences (for instance, through actual buying behavior). Intelligent pooling of simple and sophisticated data and advanced data analysis allows online companies to know significant more about their customers' preferences than offline companies do. Overall, the possibilities to collect personalized customer data as well as the possibilities to profitably use this data are much bigger on online markets than on traditional offline markets. ${ }^{3}$

A crucial phenomenon of the digital age is paying with datainstead of (or in addition to) paying a monetary price for goods. Furthermore, there are two more types of markets on which personalized data plays a significant role (Acquisti et al. 2016): markets on which bundles of personalized data are a transaction object (data trading) and markets for data extraction and privacy technologies (data software).

Although many online services and contents appear to be free of charge for users at first glance, the common price in traditional currency is usually only replaced by a data-price, which means that the provision of personalized data serves as a means 
of payment. A platform operator may pursuit several commercially profitable business models to lower the monetary price of online offers - often down to zero (Budzinski 2017; Budzinski \& Grusevaja 2017; Budzinski \& Kuchinke 2018):

i. Better personalized targeted advertising: with better and more extensive personalized customer data, advertising can better target those customers who more likely prefer the advertised product and, thus, a higher probability to actually purchase the advertised good. This increases the advertisers' willingness to pay and the overall price for advertising, leading to increasing revenues from selling advertising space by the online supplier (which in this case acts as platform; see section 2.1).

ii. Individualized goods such as individualized searching and recommendation services or individualized products. Offering goods as well as accompanying services tailormade to the customers' needs and preferences creates incentives for more transactions (increasing demand) and, thus, more sales and revenues.

iii. Improved opportunities for data-based price discrimination: based on individual consumption patterns and search histories, providers may derive more reliable assumptions about the consumers' individual willingness-to-pay. In combination with further personalized data about their ability to pay (for example income, daytime of the purchase, places of residence and work, type and brand of the used device, etc.), that may lead to data-based individualized prices. Thus, differences in the individual willingness to pay can be skimmed off, what can be used for increasing both the sold quantities and the average profit margins.

While profitable for business, consumers face several ambivalent and controversial implications from the commercial employment of their personalized data (Budzinski 2017; Budzinski \& Grusevaja 2017; Budzinski \& Kuchinke 2018):

i. On the one hand, consumers benefit from better targeted advertising because the received ads better fit the consumers' preferences (Acquisti \& Varian 2005; Tucker 2012; Brown 2016). On the other hand, the overall amount of received 
advertising increases what may disrupt consumption and increase avoidance costs. Overall, welfare effects are ambivalent (Tucker 2012).

ii. On the one hand, paying with data saves consumers' money because the monetary price decreases (sometimes even to zero), increasing consumer welfare because it can be used to buy additional goods and personalized data does not expire and can be repeatedly used to "buy" online services and contents. On the other hand, there is the question about the worth of personalized data. Whether consumers overall benefit from a transaction depends on both the subjective value they attach to their data (their preference for data protection and/or privacy) and how well they are informed about the market value and the use of personalized data (information about the actual extent of the payment). In contrast to paying with traditional currencies, paying with data lacks transparency of pricing and consumers notoriously find it more difficult to assess and evaluate the actual price. Imperfect individual information (knowledge about the commercial use and value of personalized data will diverge strongly across consumers with possible distribution effects at the expense of bad informed customers) and a lack of experience with the currency "personalized data" are problematic aspects here and give rise to asymmetric information in favor of the providers.

iii. The individualization of products and services should typically be welfare enhancing due to better matching the preferences of the consumers (Acquisti \& Varian 2005).

iv. Data-based price discrimination decreases consumer surplus in favor of producer surplus (redistribution effects) and leaves less income left for further consumption options due to eroding consumers' rents (cross-market effects) leading to an overall smaller basket of available commodities for consumers. If data-based price discrimination is widespread, then, in this consumption basket, the goods that are most strongly preferred and/or most urgently needed will be particularly expensive whereas less preferred goods may become cheaper, thus leading to a welfare-decreasing change in the composition of the basket (commodity basket effects). Furthermore, recent behavioral economics research demonstrates that data-based price discrimination yields 
negative welfare effects as soon as 'naïve' (considerably bounded-rational) consumers are present on the market (behavioral effects; inter alia, Heidhues \& Köszegi 2017; Heidhues et al. 2017). In particular in combination with market power (e.g. in narrow oligopolistic structures often prevalent in online (platform) markets) these effects are likely to outweigh the (first-semester textbook) possibility of increasing quantities in markets where the individual ability-to-pay determines demand more than the individual willingness-topay.

Next to causing different economic effects than traditional markets, data-driven markets further aggravate and complicate the task of market delineation (in addition to platform-related problems; see 2.1). If, for instance, users do not pay a monetary price for digital goods, it becomes impossible to compute SSNIP-styled price increases. Moreover, even if a data-price for contents or services would be considered, it is difficult to estimate this "price" (Haucap \& Stühmeier 2016). Furthermore, the individualization of goods further handicaps the delineation of markets.

Since only the smart combination of standard personalized data with different types of more sophisticated personalized data (including stated preferences data and revealed preferences data) allows for both extremely profitable and very exploitative business strategies at the same time, incentives to employ a walled garden strategy must be considered (Schweitzeret al. 2018). It refers to the bundling of diverse online services into one data-based platform business so that consumers conduct as many online activities as possible within this platform, allowing the platform company to maximize its knowledge about the consumer. The Chinese multi-purpose service WeChat represents an example. ${ }^{4}$ On the one hand, consumers may benefit from this one-stop shopping opportunity, on the other hand, it creates considerable power over the consumer that may be exploited commercially (in all of the above discussed

4 Originally a messaging service, WeChat (owned by Tencent) now combines services like social networking, video telephony, video portal, mobile payment system, city services (e.g. booking transportation or doctor appointments), news feed, localization and maps, job search, etc. - The (business or government) ideal that a consumer never has to leave the virtual landscape (or ecosystem) of a service and content provider while being online (and, thus, actually never really and truly enters the internet) is a vision that has always been present since the internet developed. 
ways) or - considering government-owned or -influenced/-controlled platform companies - even politically.

When companies have tracked and collected personalized consumer data, an additional source of revenue may come from selling either bundles of data or data analysis services (i.e. results from analyzing the raw data) to third parties (data trading). This may increase incentives for companies to create intransparency of data-usage towards consumers, strategically exploiting asymmetric information. As such, datatrading markets complicate the task for consumers to keep track with the commercial exploitation of their data and aggravate privacy issues, pointing to possible negative welfare implications at the borderline of consumer-welfare-oriented competition policy and consumer protection policy (Kerber 2016). On the other hand, data-trading markets may reduce foreclosure effects and, thus, promote competition: if personalized data is vital for doing business in a given market, access to such data may become an entry barrier or a means of deterrence. Notwithstanding, the virtually endless reproducibility of personal data by the consumers and the crucial role of smart data pooling and analysis rather than pure data quantity alleviate foreclosure effects in data-based markets.

The battle between the development of more and more sophisticated data tracking and extraction technologies and the development of better protection technologies (data-software markets) plays another important role. If this battle is about even, a level-playing field between suppliers and users of online goods limits several potential welfare concerns of data-based markets (Acquisti \& Varian 2005). However, if one side significantly outcompetes the other side, power asymmetries may aggravate potential problems. The vested interests behind data tracking and extraction technologies may be better organized and better organizable than the heterogeneous and fragmented group of users and consumers, probably creating considerable imbalances in the development race.

Eventually, the welfare implications of data-based markets and business strategies considerably depend on assumptions about consumer behavior and distribution of imperfect information. In a Stigler-Posner-Varian world populated by (hyper-)rational (,smart') consumers and characterized by information disadvantages of the service 
providers the use of personalized data is mostly efficiency- and welfare-enhancing and data-based abuse of market power is unlikely (Stigler 1980; Posner 1981; Varian 1997). However, a Behavioral-Economics world populated (also) by bounded-rational (,naive') consumers and with information advantages of the service providers offers considerable scope for data-based profits at the expense of consumer welfare, provides incentives for abusive strategies towards consumers and economic-dependent upstream or downstream companies, and the presence of welfare-decreasing and anticompetitive effects becomes more likely (inter alia, Taylor 2004; Hermalin \& Katz 2006; Shy \& Stenbacka 2016; Bougette et al. 2017; Heidhues et al. 2017; Heidhues \& Köszegi2017; Obar\& Oeldorf-Hirsch 2018). At the end of the day, it is an empirical question, which of these two worlds represents a more adequate description of the reality of online business in times of digitization.

\subsection{Further Challenges from Digitization}

Since the process of digitization is in full swing, it is impossible to give a definite list of further and future challenges for competition policy. Instead, the following three aspects represent a subjective choice of currently upcoming developments that may entail new challenges for competition policy institutions and practice.

One of the distinct features of the digital economy is the increasing role and importance of algorithms. This has fueled a discussion whether algorithmic pricing, i.e. prices set by algorithms, may lead towards collusive equilibria and cartel-like structures without competition agencies being able to combat because of the lack of responsible legal persons conducting the deed (Ezrachi \& Stucke 2017). This may require institutional reforms in order on include algorithm-based collusion in the cartel prohibition. The emerging economic literature on the probability of learning machines setting algorithm-based prices in an oligopolistic market and - unintended by their programmers and implementers - ending up in a collusive equilibrium derives considerably differing conclusions (inter alia, Salcedo 2015; Calvano et al. 2018; Schwalbe 2018) and skepticism about the imminence and the widespread character of this problem may be justified (Schwalbe 2018). It looks significantly more likely that pricing algorithms may be employed to conceal deliberate cartels from prosecution agencies, for instance, by employing price circles and complex price movements 
instead of a constant cartel price. This may make it more difficult for competition agencies to detect price cartels and it may require new detection and analysis techniques in competition policy practice (as well as awareness of such developments in courts) but it does not require institutional change, i.e. a change of the law.

The process of digitization also changes the ways of goods production (internet of things, smart production and manufacturing, machine-to-machine communication, industry 4.0) and consumption (digital personal assistants). The first case addresses intelligent systems (or ecosystems) of digital networks, which may allow for a largely self-organized industry production. This implies intensive communication (also among "things") and interconnectedness along and across supply chains requiring new forms of (data-based) inter-company cooperation. While this development offers significant welfare-enhancing potentials, the extended inter-company cooperation along supply chains may raise antitrust concerns similar to vertical integration. As a consequence, the tendency towards a rather lenient competition policy enforcement against vertical cooperation and integration may need to change and a reinvigorating of antitrust control of vertical cooperative and collusive structures may be necessary (inter alia, Salop 2018). Crucially, this may include both securing the access to data if this is essential for a third-party to provide a competing service or product (danger of foreclosure) and preventing the sharing of data if this leads to collusive arrangements (Kerber \& Frank 2017). Enhanced cooperation across supply chains may entail concerns about collusive arrangements among (direct or indirect) competitors as well as requiring a new assessment of conglomerate cooperation structures ( $\operatorname{Lim} 2017)$ ). A further concern relates to the issue that even a welfarepromoting cooperation network can form the structure for subsequent anticompetitive collusive arrangements once the cooperation has generated sufficient trust between the companies. While this altogether may not require a change of law, the rephrasing and modernization of guidelines and statements of policy directions may be necessary.

Next to smart manufacturing, also elements of smart consumption may create both considerable benefits for consumers and pose new challenges for competition policy. In order to provide smart services, suppliers need comprehensive and far-reaching 
personalized data from consumers about their economic (and other) behavior, aggravating the issues discussed in section 2.2. A particularly interesting smart service, from an economic perspective, is the offering of so-called digital personal assistants (DPAs) such as Apples Siri, Amazons Alexa or Facebooks $M$. They manage and organize everyday duties and jobs of consumers, like a personal butler, including such with economic relevance. For instance, the DPA may take over the responsibility for routine shopping of daily goods (washing powder, cat food, etc.), e.g. in a smart home, it may notice if they are empty and automatically order new units - based upon its knowledge about the preferences (brands, etc.) of "its" user. Moreover, Alexa and her sisters also help with non-routine shopping decisions by providing information about offerings as well as ranking and recommending the best options - again according to the perceived preferences of their users. While this obviously benefits consumers by considerably reducing transaction costs, it also entails some anticompetitive concerns (Budzinski et al. 2018; Ezrachi \& Stucke 2018; Gal2018). From an economics perspective, the relation between a user and her DPA is a principal-agentrelation with the user being the principal and the DPA being the agent. The economics of principal-agent-relations show that the agent virtually always pursuits her own interests next to and interfered with the principal's interests. The scope for interests deviating from the preferences of the principal becoming relevant increases with a decreasing control over the agent - be it because control is impossible or impractical (or just not done). In the case of DPAs, the user's ability to exert control depends on information asymmetries but should usually be quite high. However, her willingness to permanently control the DPA may be rather low because the advantages of using a DPA - reduced transaction costs - crucially depends on not controlling everything the DPAs does, decides, or recommends. Now, this may only be a concern if the DPA also follows other interests than the ones of the user. This scenario is particularly relevant if the producer of the DPA service has also other business interests because of a vertical or conglomerate integration with other businesses. If Amazon's Alexa is to buy new cat food, for instance, Amazon surely has an interest to buy it from Amazon - irrespective of whether Amazon's retailing offering is the best match for the user's preferences. Such interrelations obviously entail considerable antitrust concerns, in particular if the market of DPA services becomes dominated by a single 
supplier, for instance, because of platform effects (Budzinski et al. 2018). However, the presence of naive users may allow for anticompetitive scope in an oligopolistic DPA market as well (similar to the reasoning in section 2.2). Furthermore, the walled garden strategy may enjoy reinforced popularity. Again, this example of smart consumption points towards the necessity of an increasing sensitivity towards vertical and conglomerate interrelations when it comes to competition policy implications. In general, both the implications of platform economics and data economics (including upcoming developments like smart supply and smart consumption) point to the necessity to re-assess the importance of vertical and conglomerate antitrust concerns (Petit 2016; Lim 2017; Salop 2018). The previously dominating paradigm that vertical and conglomerate arrangements and strategies are predominantly unlikely to cause consumer welfare damage is well-established - albeit mostly not in the codified rules of competition law but in guidelines, enforcement practices as well as in the minds of enforcers, lawyers and judges. Therefore, institutional change - of formal and informal institutions - is necessary to improve the protection of competition vis-à-vis new challenges from digitization. Adequate competition rules and policies safeguard the mostly beneficial economic development towards the digital economy by frustrating anticompetitive and welfare-decreasing strategies and arrangements without destroying the beneficial process and its inherent innovative power itself - something that non-antitrust based regulation is likely to cause.

\section{The 2017 Competition Policy Reform in Germany - A Paragon for Europe?}

After some controversial political discussion, a considerable reform of German competition law came into force in June 2017. One of the main reasons for initiating this competition policy reform was the ongoing process of digitization and one of the main targets was to change antitrust institutions in a way to make them better fit to a digitized world and digitized markets, especially online markets (Deutscher Bundestag 2017: 2). Besides some other changes (e.g., regarding procedural aspects of 
the so-called Ministererlaubnis ${ }^{5}$ and the enforcement of damage claims by cartel victims), the most relevant institutional changes relate to aspects of digitization such as online platform markets, the competitive role of (big) data, consumer protection in the digital age, and competitive relations between offline and online media (overview: Budzinski 2017).

\subsection{Digitization-related Elements of the German Reform}

\section{Market Power of (Digital) Platforms}

First, the competition law now includes regulations concerning the special features of digital platforms. The newly added § 18 (3a) GWB mandates competition authorities to explicitly consider the economic features of platforms with respect to the delineation of digital markets, concerning the determination of market power and possible dominant positions in such markets, and regarding the evaluation of possible restrictive practices. In addition, new platform-related market power criteria were included in the law. These criteria are (i) direct and indirect network effects, (ii) the parallel use of several services (multi-homing) and the effort for users coming from the change of services (switching costs), (iii) economies of scale connected to network effects, (iv) access to data relevant for competition, and (v) innovation-driven competitive pressure. The Federal Ministry for Economic Affairs and Energy must report to the legislative bodies after three years on the experience with these new regulations (§ 18 (8) GWB).

\section{Competitive Role of (Digital) Data}

The newly added $\S 18$ (2a) GWB states, that it does not preclude the assumption of a market when services are provided free of monetary charge. In other words, the existence of monetary flows does not represent a constitutional element for a market in the sense of antitrust law. This clarification targets primarily digital markets, where service and content providers often do not charge a monetary price from consumers but, in return, collect and utilize personalized data of the users.

5 The Ministererlaubnis grants the federal minister of economic policy the power to overrule prohibition decisions in the area of merger control by the Federal Cartel Office on the grounds of public interest considerations (Budzinski \& Stöhr 2018). 
In merger control, the institutional provisions governing when a merger is subject to review by the competition authorities were revamped in view of the increasing role of (personalized) data in competition, particularly in digital and online markets. To avoid the regulation of competitively unproblematic mergers among relatively small companies that have little impact on the market, the GWB defines minimum revenue thresholds, which must be exceeded in order to mandate a merger control review of a particular merger ( $§ 35$ (1) GWB). So far, this limit has been $€ 500$ million in worldwide cumulative revenues of all involved companies as well as domestic revenues of at least $€ 25$ million of one company involved in the merger and at least $€ 5$ million of another involved company. ${ }^{6}$ These stipulations were complemented by an additional transaction value threshold: if the first two conditions are met but not the third, the proposed merger is still subject to merger control if the value of the compensation (usually the transaction volume, i.e. the purchasing price of the acquired company) exceeds $€ 400$ million and the acquired company significantly operates in a domestic market ( 35 (1a) GWB). This implies that now such mergers are subject to review by the FCO where the value of the acquired company is not determined by revenues but predominantly by other valuable assets (e.g. data stocks, technologies, innovations, intellectual property rights, etc.) as it often happens with upcoming innovative start-ups in the digital economy.

\section{Consumer Protection and Competition Policy}

One of the most controversially discussed topics in the context of the reform was the question of whether the FCO should acquire competences in the field of consumer protection policy. Traditionally consumer protection law in Germany is strictly separated from competition law, especially regarding enforcement, whereas in the Netherlands, for example, since April 2013 a common authority is responsible for both competition and consumer protection (Authority for Consumers and Markets 2018). With Germany's 2017 reform, the FCO received consumer protection competencies for the first time, albeit strictly limited. Now, the competition authority can conduct

6 In addition to the protection of micro-mergers from regulation, these thresholds also serve as the vertical delimitation of powers for the merger control of the European Commission and the (incomplete) horizontal allocation of competencies between the member states of the European Union (Budzinski 2006). 
so-called sector inquiries, if there is reasonable suspicion of significant, permanent or repeated breaches of consumer law, which may affect the interests of a large number of consumers - unless these violations fall within the remit of another federal authority ( $(32$ e $(5)$ GWB). These sector investigations were first implemented into the law with the $7^{\text {th }}$ amendment of the German competition law in 2005. The aim is to gain comprehensive knowledge about the examined markets, not necessarily to file claims against individual companies. This knowledge is in turn an important database for further proceedings of the FCO (Bundeskartellamt 2018).

This addition to competition law aims primarily at digitization effects and online markets, for example violations of the general terms and conditions on online platforms (as in the current German Facebook case; Budzinski \& Grusevaja 2017). In addition, the new regulation concerns systematic violations of the Law against Unfair Competition (UWG), which may be difficult to detect by civil law enforcement alone.

\section{Facilitating Cooperation between Press Publishers}

The last aspect considered here is the extension of special regulations for (offline) press publishers. Publishers of printed press products (newspapers and magazines) are already exempted from the prohibition of cartels in relation to vertical agreements (resale price maintenance). In addition, horizontal cooperation between press publishers is now facilitated. The general prohibition on cartels ( $§ 1$ GWB) no longer applies to agreements between newspaper or magazine publishers in case they want to cooperate as long as this cooperation strengthens the economic basis of the companies involved, in regard of inter-media competition ( $\$ 30$ (2b) GWB). However, cooperation in the editorial area still is explicitly excluded and continues to be covered by cartel prohibition. The explicit reference to inter-media competition is a clear signal that the underlying goal of this institutional change is facilitating the economic cooperation of traditional newspaper publishers to strengthen their competiveness vis-à-vis new digital and online media. And with that, ultimately protect the press variety. 


\subsection{Pros and Cons of the German Reform}

\section{Market Power of (Digital) Platforms}

The list of factors introduced in $\S 18$ (3a) GWB displays a remarkable fit to the state of platform economics (see section 2.1). It adds access to competition-relevant data, which we discuss in the context of data-driven markets. As a factor of market power, an emphasis on the exclusivity of data owned by a company may have been helpful because big data is not per se problematic due to the reproducibility and multi-use of personal data by the consumers (see section 2.2) (Schwalbe 2017). Two relevant factors are, however, missing from the list: the heterogeneity of consumer preferences and compatibility between services. Both represent relevant factors that should not be neglected when analysing digital platforms in an antitrust context. Compatibility is addressed indirectly by the reference to switching costs. However, there is more to compatibility and interoperability than switching costs (Kerber \& Schweitzer 2017). Its relevance also relates to its characteristic as a strategic choice by service providers who can decide to allow for compatibility with competitors' services and products or block this. Incentives to choose the blocking option may be low in competition, however, a market powerful company may employ it to protect and further strengthen its dominance. It represents an interesting observation that many countries enforce compatibility in telecommunications (e.g. mobile telephony) in order to preserve competition and challenge incumbents, whereas dominant social network service providers or instant messenger service providers are allowed to deliberately create incompatibility with fringe competitors (as well as with maverick competitors). Such a strategy choice is profitable for market powerful companies but questionable and worrying regarding consumer welfare. Strategically generating incompatibility, strategically complicating and handicapping multi-homing as well as strategically increasing switching costs may lead to a tipping of a platform market, i.e. the market turns from a (competitive) oligopoly into a monopoly or a quasi-monopoly. Thus, these strategies may already be harmful before a platform dominates a market because they facilitate the way towards an incontestable dominance. This points towards the necessity to broaden the scope for combating abuse strategies beyond the borders of dominance. For instance, the burden of proof in abuse-of-dominance 
cases generally appears to be "unsatisfiably high" (Podszun 2018: 5-6) and a reinvigorating of enforcement against exploitative abuse (towards consumer but also towards economic-dependent companies) remains desirable (Bougette et al. 2017). Altogether, however, the $9^{\text {th }}$ amendment represents an improvement and contributes to adequate competition rules in the light of digitization.

\section{Competitive Role of (Digital) Data}

Here, the German competition policy reform entails a number of important improvements. First, the clarification that transactions without monetary remuneration can constitute markets unambiguously makes paying-with-data markets subject to competition law, which is absolutely necessary from an economic point of view. This may be an important precondition to combat possible negative consumer welfare effects from data-based business models like excessive advertising, inflated data-prices or data-based price discrimination - without eroding such innovative business models altogether. Second, complementing revenue-based merger control provisions by additional transaction- and value-based thresholds addresses a relevant phenomenon of mergers and acquisitions in the digital business world. Young innovative companies may yield considerable transaction values despite a lack of significant revenues. Their acquisition by large, market-leading incumbents may raise antitrust concerns if they represent innovative mavericks, who reinforce dynamic competition by developing and introducing innovative, (for the incumbent) disruptive business models and ideas. Powerful incumbents may impede dynamic competition by effectively taking these mavericks off the market through an acquisition. Therefore, it is important for welfare that competition authorities review such mergers. In both cases, the institutional reform enables the competition authority to better identify and combat innovative anticompetitive arrangements and strategies in data-driven markets. At the same time, it preserves the welfare-enhancing innovation dynamics in these markets as only the in-depth competition analysis by the authority will reveal whether significant antitrust concerns need to be combated. In contrast to sector-specific regulation, welfare-increasing innovation dynamics and incentives remain unrestricted. While the institutional changes in German competition policy generally improve antitrust dealing with data-driven markets, the prospective and upcoming issue of data- 
based price discrimination remains neglected. In the light of current economic theory, it may not be sufficient to consider data-based price discrimination as an anticompetitive strategy reducing consumer welfare only in the case of market power (as an example of a possible abuse strategy). From an economics perspective, however, incentives to implement data-based price discrimination may arise considerably below market power thresholds in the digital economy where markets are datadriven. And if behavioral economics represent an adequate description of consumer behavior, then welfare-reducing effects are likely to be imminent. The issue may have been neglected in the $9^{\text {th }}$ amendment because it is largely something yet to happen - despite already existing elements within dynamic pricing systems (e.g. online airline ticket sales) and test runs (e.g. Amazon; Budzinski \& Köhler 2015). However, it will be an issue for possible future reforms, also because its widespread implementation entails potential to (further) reduce the popularity of the market economy within the population since, once it is recognized, it is likely to violate widespread fairness perceptions (in addition to the negative consumer welfare effects).

\section{Consumer Protection and Competition Policy}

Whether consumer protection policy and competition policy should be conducted by the same agency in a one-stop shop or remain separate areas of enforcement is a highly interesting and very relevant discussion, which, however, goes beyond the scope of this paper (for some general insights into the new conditions of consumer protection see, inter alia, Ezrachi \& Stucke 2016; Decker 2017; OECD 2018). Even though the $9^{\text {th }}$ amendment only allocates sector inquiry powers (but no enforcement or sanction powers) to the FCO, it does represent an initial step towards combining these two policy areas.

\section{Facilitating Cooperation between Press Publishers}

In contrast to the other reform elements who seek to improve the protection of competition in digital markets, the far-reaching facilitation of horizontal cooperation and collusion among publishers of printed press obviously rather targets the protection of a traditional (and outdated?) business model against digitization and against competition from new competitors from the digital world. While it is already doubtful 
whether the preservation of pre-digital publishing structure represents a desirable goal, it moreover appears to be improbable that such a goal may be reached through allowing for collusive structures. A significant improvement of competitiveness towards new digital press goods and a necessary adaptation to changing consumption behavior can hardly be achieved by cementing obsolete models. From an economic perspective, this element of the German competition policy reform is certainly no paragon for any other reform.

\subsection{Further Reform Plans in Germany}

Despite the very young history of the $9^{\text {th }}$ amendment, preparations for a $10^{\text {th }}$ amendment of German competition law have already started again putting a focus on digitization-related institutional change. The process towards such a $10^{\text {th }}$ amendment is expected to take up to two years. First, a study was commissioned with the goal to explore reform needs regarding the norms on abusive practices. The final report was submitted in August 2018 (Schweitzer et al. 2018). Second, in September 2018, the German government installed a commission called Competition Law 4.0 targeting the modernization of competition law and the harmonization of the institutional framework for the digital economy. It shall focus on competition policy recommendations - both for Germany and Europe - regarding the increasing importance of data-driven markets and business models, the proliferation of platform markets, and the emergence of industry 4.0 (smart production and smart consumption). ${ }^{7}$ Next to the protection of competition from powerful and dominant (digital) companies, the commission shall, inter alia, seek for ways to promote the emergence of European players in digital markets and to fuel digital innovation and investment in digital technologies. It is expected to conclude its work by autumn $2019 .^{8}$ Since the work

A rather similar commission was implemented in the UK, also with a view to a September 2019 deadline. See https://www.gov.uk/government/news/work-kicks-off-to-examine-digital-competition-in-uk (accessed September 20th 2018). European Competition Commissioner Margrethe Vestager called a special advisory panel in 2018, set to deliver a report by March 2019 on virtually the same topics. See https://ec.europa.eu/commission/commissioners/2014-2019/vestager/announcements/commission-appoints-professors-heike-schweitzer-jacques-cremer-and-assistantprofessor-yves_en (accessed September 20th 2018).

8 The commission's members are predominantly from law but it notably also features the head of Germany's Monopolies Commission, antitrust economist Achim Wambach. 
of the second commission has just begun at the time of writing, we focus on the final report of the first commission in this section.

The study argues from an economics perspective that there can be cases where negative competition and welfare effects may be the consequence of unilateral strategies by enterprises with market positions below the level of dominance. Thus, the current competition policy regime in Germany (even after the 2017 reform) and also in Europe entails the danger of so-called false negatives, i.e. cases of anticompetitive conduct that competition authorities do not or cannot combat. Predominantly, three case constellations are viewed to present need for institutional change (Podszun 2018; Schweitzer et al. 2018):

(i) Platform markets with a tendency towards tipping (from a competitive market to a monopolistic or quasi-monopolistic market), i.e. markets characterized by strong positive network effects, should be addressed by a new provision addressing the biggest platforms with superior growth-rates in a market - irrespective of whether they match market dominance thresholds or not. In such cases, impeding competitors should be prohibited if this may foster tipping. Similar conduct within narrow oligopolies of similar sized platforms, in particular towards fringe competitors and oligopoly outsiders should also be prohibited. This new prohibition provision below the market dominance threshold particularly addresses strategic complicating and/or handicapping of multi-homing and/or switching to other platforms (e.g. in the case of single-homing), for instance, through artificial incompatibility, exclusivity obligations (or incentives), sophisticated tariff- and pricing structures, artificial switching costs (including features strategically complicating or impeding switching), etc. (Schweitzer et al. 2018: 59-64).

(ii) In the digital world, market power and its abuse may not only result from strong positions in supply or demand but also from a privileged position as a relevant intermediating force. Therefore, the study recommends adding power in intermediation to the law, definitely regarding transaction platforms but possibly also regarding non-transaction platforms (Schweitzer et al. 2018: 42-43, 66-78). Furthermore, manipulating information 
should become a regular example for the abuse of such an intermediationpower position.

(iii) In data-driven markets, access to data may be necessary to compete; therefore, the study encourages further reflections on data sharing obligations. It proposes to assume an abusive impediment if, within a value-creating network, an enterprise is blocked from access to automatically generated data that is necessary for some substantial value creation (Schweitzer et al. 2018: 78-83).

In order to address these case constellations, the study recommends adapting provisions about relative market power and economic dependence. By contrast, it explicitly rejects the idea to complement the existing prohibition of an abuse of dominance (Art. 102 TFEU; § $19 \mathrm{GWB}$ ) by a prohibition of (deliberate) monopolization and attempts to monopolize similar to U.S. antitrust law (Schweitzer et al. 2018: 43-45). Furthermore, it considers replacing the prohibition of abuse of dominance by a SIEC ${ }^{9}$ style test à la merger control, i.e. a general prohibition of enterprise strategies that significantly impede effective competition, irrespective of market power (market power would merely become a facilitating factor for conducting such strategies but not a necessary condition anymore). However, the study emphasizes the danger of an increasing number of false positives, i.e. competition policy interventions against efficient, procompetitive enterprise strategies as well as an increasing legal uncertainty because abuse control, in contrast to merger control, is no ex ante regulation (Schweitzer et al. 2018: 45-47).

Thus, the study proposes a major reform of $\S 20 \mathrm{GWB}$, dealing with relative or superior market power and economic dependence (Schweitzer et al. 2018: 47-59). More precisely, the authors suggest dropping the hitherto restriction of economic dependence situations to small-and-medium-sized enterprises (SMEs) in § 20(1) GWB, so that all companies being in an economic-dependent position (i.e. facing superior market power) could be a potential victim of abusive practices (Schweitzer et al. 2018: 56-59). So far, it was legally not possible to suffer from an abuse of superior

9 Meaning "Significant Impediment of Effective Competition" 
market power if you are not a SME - but economically, of course, it is: "If food producer Nestlé, for instance, needs food retailers like Edeka or Amazon, or if a large insurance company depends on access to a comparison portal, such undertakings may now rely on $\S 20$ GWB despite their size and even if the other party is not dominant" (Podszun 2018: 3). Such a reform would shift the focus of the respective provision away from a protection of SMEs towards a general abuse prohibition of superior market and bargaining power and, thus, push it more in line with modern economics.

In addition, the study suggests informal institutional changes. It encourages authorities to be more flexible with proof in abuse cases (= lower implicit thresholds) and expresses optimism that courts will be flexible enough to handle that as well as difficulties with market definitions (Podszun 2018: 3; Schweitzer et al. 2018: 34-40). According to the reasoning in the study, it should be sufficient to identify scope for company behavior not restricted by competitive pressure (and irrespective of market shares), i.e. the powerful company does not need to pay consideration to competitors' reaction to its own strategy in question (missing/absent competitive control of the companies behavior), combined with a sound theory of harm - somewhat analogue to different competition intensities between pairs of companies in a heterogeneous market regarding unilateral effects in merger control. A market-powerful position of a company would then be concluded from the empirical existence of an unilateral conduct not subject to competitive control with an anticompetitive effect. Market power, then, is not only an absolute phenomenon on a pre-defined market but also a relative phenomenon in the interrelation of economic agents (be it - horizontally, vertically or in a conglomerate way - among companies or towards consumers). Regarding German law, this focuses on a more flexible handling of $\S 20$ (3) GWB, i.e. relative market power in horizontal relations. An amendment of the law is not deemed to be necessary.

Furthermore, the authors suggest continuing the path of the $9^{\text {th }}$ amendment with respect to merger control (introduction of transaction value threshold) and focus on preventing the acquisition of mavericks by powerful companies. Consequently, the study proposes a prohibition of acquisitions that take potential rivals off the market (as a novel violation of the SIEC-criterion). 
In contrast to these reform proposals, the study sees no need to re-address conglomerate power as a relevant issue of abuse control (Schweitzer et al. 2018: 83-91). Although it admits an increasing relevance of conglomerate arrangements and strategies in the digital economy, the study conjectures that most cases should fall under traditional dominance criteria in at least one of the relevant markets so that no amendment of the law is necessary. Remaining cases not captured by the existing law could be dealt with a more flexible approach to relative market power in horizontal relations ( $§ 20$ (3) GWB). However, the authors also lament deficits in economic theory addressing digitization-driven new forms of conglomerate power (Schweitzer et al. 2018: 89), implying that new insights may cause a change in their assessment.

Generally, the fundamental direction of the study's recommendations is to put emphasis on stopping the rise of monopolists instead of waiting with interventions until a company is settled into a dominant position, i.e. a tougher stance on companies on the rise towards incontestable dominance. ${ }^{10}$ Podszun (2018: 6) derives as the key lesson: "Keep markets open, otherwise intervention may be too late." These further reform proposals address some - but not all - of the shortcomings identified for the $9^{\text {th }}$ amendment.

\section{Towards a Digitization-focused Reform of EU Competition Policy?}

While there are many similarities between antitrust institutions on the EU-level and on the German level, they are not identical. Thus, the question arises whether a reform mirroring the German 2017 amendment would be necessary or, at the least, helpful to improve the fit of European competition policy with the peculiarities of competition in the digital age as well. Since the provisions to facilitate enhanced cooperation among traditional press publishers cannot be classified as sensible competition policy from an economic perspective, we focus on the other reform elements, in particular on the explicit introduction of platform economics and the role of personalized data.

10 Podszun (2018: 4) provides a similar conclusion adding: "This is a viable lesson from the Google cases that achieved too little too late." 


\subsection{Platform Economics in Current EU Competition Policy}

The unsuitability of traditional market delineation tests for platform markets and paying-with-data markets is already considered in recent EU cases. For example, in the prominent Google Shopping case, opened in 2010 and ending in summer 2017 with a fine of $€ 2.42$ billion for "abusing dominance as search engine by giving illegal advantage to own comparison shopping service" (European Commission 2017b). The EC found that Google used its high market shares in the market for search engines (more than 90 per cent in all 31 states of the European Economic Area over several years) and high barriers to entry (because of network effects) to give its own shopping comparison service a prominent placement in search results while artificially lowering search entry ranks of rival comparison shopping services. That led to less user clicks and traffic on those rivals' platforms and an increase of traffic on and of market shares for Google's own shopping comparison site. This distortion of competition lowered the benefits for customers, like genuine choice and innovation processes, all over Europe (European Commission 2017b).

The Google search engine constitutes a platform, offering monetary free (but paid with data) search services for customers and paid-for advertising space for companies. The same applies to the shopping comparison service Google Shopping, which operates on a different relevant goods market (European Commission 2017a: 28). Therefore, the EC considered platform-related peculiarities in market delineation to some extent when refusing Google's claim that the EC should have carried out a SSNIP test. This was justified by Google offering its services for free (without a monetary price) to users (European Commission 2017a: 54). Instead of using a SSNIPtest, the EC examined the market for general search services and the market for comparison shopping services by analyzing demand substitutability, supply substitutability, and potential competition (European Commission 2017a: 28). Furthermore, the EC mentions indirect network effects and positive feedback effects on two-sided platforms in connection with the general Google search engine as a barrier to entry and/or expansion (European Commission 2017a: 63-65). Furthermore, the EC applies elements of platform economics to assess markets, market power and (anti-) competitive effects in other recent cases (for instance, Facebook/WhatsApp 2014; Fox/Sky 2017; Google Shopping 2017; Google Android 2018). 


\subsection{Economics of Personalized Data in Current EU Competition Policy}

The inexperience of European competition policy enforcers with paying-with-data business models and privacy-related issues shows in the Facebook/WhatsApp merger case (Deutscher 2017a, 2017b). In fact, the EC considered - next to platform effects - that access to personalized data represents a potential barrier to entry and, therefore, a potential source for market foreclosure as well as a potential cause for increasing market power. However, the EC's analysis on both the effects and the probability of Facebook combining its datasets with WhatsApps lacked a sound data economics fundament. Instead, the EC concentrated on platform-related effects like the multi-homing tendencies of many users, therefore, viewing both merging companies as competitive complements instead of being close competitors/substitutes in terms of data-based business models. ${ }^{11}$ Besides that, the EC somewhat naively relied on statements of the merging parties regarding ostensible technical impossibilities to combine their datasets, which not surprisingly turned out to be wrong retrospectively. ${ }^{12}$

The main problem of competition policy showing in this case is the reliance on monetary assessments of most of the relevant aspects in an actually data-driven environment. These concepts are not sufficient to use in digital markets: a company with low revenues (like, e.g., WhatsApp) may appear to be of low competitive relevance when only looking at monetary terms. Nevertheless, through their datasets such companies can in fact be important players in the market, furthermore playing a maverick role for future competition. Thus, both unrecognized current competitive practices and underestimations of the role of the potential competitor of an acquired company for the buyer (as it happened in the Facebook/WhatsApp case) may occur. It can be an indication if (especially relatively young and innovative) companies

11 „Furthermore, the EEA market for consumer communications apps features a significant degree of "multi-homing", that is, users have installed, and use, on the same handset several consumer communications apps at the same time. In particular, WhatsApp and Facebook Messenger have been reported as being the two main consumer communications apps simultaneously used by the majority of the users in the EEA. This fact suggests that the two consumer communications apps are to some extent complementary, rather than being in direct competition with each other." While in economic theory, multi-homing points towards competition among platforms, interestingly, it is interpreted to signal the opposite here.

12 This providing of misleading information led to a fee of $€ 110$ million for Facebook in May 2018 (European Commission 2017c). 
achieve very high stock market valuations or purchase prices in case of takeovers, despite low sales figures - a potentially high economic value of the companies could probably be the reason for that and should be examined by competition authorities. Though, this examination cannot be enforced if a merger is not subject to institutional control and/or regulation at all or is released due to "low importance" because of too low monetary turnovers combined with an inadequate assessment of the underlying data-business logic.

A recent (but still pre-reform) German case may serve to illustrate the pitfalls of purely monetary thresholds for merger control in the face of data-driven business models. In 2016, the two clearly leading long-distance bus operators in Germany (FlixBus and Postbus) announced a merger. In a "normal" case, this merger of quasiduopolists would have been investigated by the FCO. However, because of the special business model of the companies and the market as such, the turnover thresholds for German merger control were not exceeded and the authority did not have any legal basis for intervention (Bundeskartellamt 2016). In Germany, this gap was closed with last year's amendment introducing transaction value thresholds (see section 3.1). EU merger control, however, is still based upon (monetary) turnover thresholds implying that the EC must rely on national competition regimes and their - vastly varying but predominantly monetary - thresholds to capture data-driven mergers with relevant anticompetitive effects and refer them to the EC.

Regarding an adequate assessment of data-related (anti-)competitive effects, the EC just decided another relevant case. In September 2018, the EC cleared Apple's (here especially the online music streaming platform Apple Music) acquisition of Shazam, a leading music recognition app (identifying playing music by its sounds and referring the app's users to streaming and downloading services). The EC justified its indepth investigation with two theories of harm: firstly, whether the combination of Apple's and Shazam's consumer data could lead to a powerful market position of Apple Music because the combined entity would be able to directly target competitors customers, and, secondly, whether Apple could be able to harm competitors after the merger by stopping referrals from Shazam to their services (European Commission 2018). Although platform-related effects like network effects and multi- 
homing may have been neglected if the brief press release is indicative, the investigation did focus on the competitive role of data, which is a positive first step in the right direction. Nevertheless, in the similar Facebook/WhatsApp case the EC also analyzed a possible combination of datasets of the two merging parties and came, erroneously, to the conclusion that it would not be beneficial or even possible for the companies to do so (European Commission 2014b, 2017c). In the Apple/Shazam case, a combination of both datasets could be profitable for Apple in that regard that using Shazam's data would allow Apple to improve its suggestion services. Shazam is used by consumers to get to know new music that was not suggested to them by a streaming service or else, but that they overheard in their direct environment. With the information collected through Shazam, Apple has access to better information than just the previously heard playlists and/or songs. Recommendation services are among the main services of music streaming platforms. The better this service, the more consumers are potentially attracted. It is very unlikely that Apple will ignore this competitive advantage. In particular, since the combination of data technically should hardly pose any problems. Furthermore, the incentives to bias the referral of Shazam users towards Apple Music will be considerable from an economics perspective. However, as the press release can offer only very brief insights into the EC's reasoning, it remains to be seen what the detailed case report of the EC will look like in order to be able to carry out a deeper analysis of the case.

An additional area where data-based effects will play a crucial role are markets where companies act both as a marketplace and as a merchant on this (or a related) marketplace. The "dual role" of Amazon as a marketplace platform for third-party shops and as a retailer of the same/similar goods involves issues about the use of marketplace data from third-party shops to optimize its own retailing business and/or benefit its own competing offers at the detriment of the - possibly economic-dependent - third-party shops. Apple and Google enjoy similar "dual roles" when it comes to their app stores (representing marketplaces) where their own products compete with third-party apps. Economic dependence may be strengthened here by the exclusivity of the Apple App Store for devices with Apple operating system and of Google Play for those using Google's Android operating system. 


\subsection{Do European Rules Need Institutional Change?}

In general, the institutional framework of European competition policy is proving to be rather flexible, based on rather general provisions that offer sufficient scope for introducing economically sound theories, concepts and techniques when it comes to antitrust cases involving digital platforms and data-driven markets. An amendment of the law - in case of the provisions codified in the Treaty of the Functioning of the European Union not a realistic option anyway - may not be necessary. However, next to codified law, guidelines play an important role in European competition policy, facilitating the anticipation of competition policy decision and, thus, improving the deterrence of anticompetitive conduct and arrangements as well as legal certainty. The merger and antitrust guidelines of the European Commission are not very current. For instance, the latest revision of the guidelines for horizontal mergers took place in 2004, the guidelines for non-horizontal mergers were last revised in 2008 (European Commission 2014a). Therefore, it is not surprising that aspects of platform economics and economics of personalized data are not explicitly included here. As recent cases show (see sections 4.1 and 4.2), this does not preclude the EC from applying platform economics and (to a considerably lesser extent) the economics of personalized data. However, a revision of the guidelines, introducing platform-related (like in the German law) and data-related aspects to, inter alia, market power measures and assessments, would represent a welcome clarification. And, in particular regarding data-driven market conduct, there is also a deficit regarding economics in competition policy practice.

A similar assessment relates to two necessary policy changes. The first continues a trend that the rising importance of unilateral effects analysis in heterogeneous and oligopolistic markets has already fueled. While the task of market delineation remains relevant, its relative importance further decreases. In an antitrust world where the (simple) economics of (standard) homogenous goods dominate, sound market delineation is paramount to exactly quantify market shares which play an important role in assessing (anti-) competitive effects. ${ }^{13}$ However, in the more complex world

13 Consequently, cases were quite frequently decided upon market delineation issues in the past, particularly in the courtroom. 
of heterogeneous goods, an anticompetitive impact on the process of competition does not depend that strongly on market shares anymore and, consequently, market delineation loses its gatekeeper character for competitive analysis (Farrell \& Shapiro 2010; Kaplow 2011, 2015). The effects of digitization further decrease the role of market delineation for the antitrust assessment of business practices and intercompany arrangements both due to the multisided platform character and due to the peculiar role of data (see section 2.1 and 2.2). Since the role of market delineation is not codified in "hard" law, a policy change towards a less decisive role of complete and uncontroversial market delineations does not require a change of law. However, it appears to be questionable whether competition agencies and, in particular, courts and judges will be open enough to frictionless change from traditional practices towards economically more adequate treatments of cases involving digital goods. The danger of decision errors based on reluctance to abandon "old-fashioned" (in relation to digitized markets) practices and embrace new perspectives is imminent. It may happen that a case actually involving severe anticompetitive effects may be cleared (directly by the EC or subsequently through a court in the legal revision procedure) on formalistic grounds of market delineation controversy, even though the latter may be rather irrelevant for the anticompetitive effects in question. Therefore, clarifying guidelines on the (limited) role and adequate techniques of market delineation in digital (platform, data-driven) markets would represent a helpful tool to safeguard an economics-based case treatment - also on the European level.

The same logic applies to other digitization-driven changes in competition policy, altering presumptions about the probability of anticompetitive effects in cases of (i) relative market power and economic dependence, (ii) vertical integration, and (iii) conglomerate power (see sections 2.3 and 3.3). In the area of abuse of dominance, the nature of digital goods markets requires a stricter and more active approach because the economic logic of these markets often favors narrow oligopolistic structures, in many markets on an intercontinental or even worldwide scale. In these markets, anticompetitive effects resulting from economic dependence gain importance and need to be addressed. However, will courts follow a more flexible use of antitrust doctrines and instruments, so that they can be used properly in digital markets, with- 
out an explicit and reasoned documentation of the underlying policy change (including its application areas and its limits) in respective guidelines? Along the same lines, reinvigorating enforcement against vertical issues including moving away from the dominance of price and quantity-based assessments (data-driven markets and business models!) may require stronger signals than "just" changes in the practice of case treatment. Eventually, the issue of a possible new importance of conglomerate power has not really been touched in digitization-related competition-policy-reform discussions so far.

Maybe the one area where a change of law would be helpful from an economics perspective is merger regulation. Here, adding transaction-value-based thresholds following the German example would reduce the necessity to rely on national referrals (and, thus, on sound and adequate national rules) in order to capture cases with community dimension in the digital economy and contribute to closing an enforcement gap.

\section{Conclusion}

The process of digitization changes the nature of many markets along with entailing new business models as well as new pro- and anticompetitive strategies. In order to reap the benefits for society but preventing the pitfalls, competition policy must adapt to the challenges provided by digital markets. From an economics perspective, the two major trends coming along with digitization are digital platform markets and data-driven markets (see sections 2.1 and 2.2). The peculiar economics of these types of markets imply, inter alia, an increased relevance of market power position both in terms of absolute and relative market power (economic dependence), a decreasing relevance of short-run price and quantity effects (without rendering them unimportant), a decreasing importance of a complete and quantitative market delineation as well as an increasing importance of (new) maverick competitors. Furthermore, both the implications of platform economics and data economics (amplified by upcoming developments like smart supply and smart consumption; see section 2.3) point to the necessity to re-assess the importance of vertical and conglomerate antitrust concerns. 
In 2017, German competition policy has implemented a significant reform of competition law that is predominantly focused on digitization related issues and tackles some of the new challenges, in particular regarding platform economics and the role of personalized data (see sections 3.1 and 3.2). Furthermore, talks about and plans for a more comprehensive reform, again related to digitization, are already ongoing (see section 3.3), focusing on strengthening the enforcement against dominanceabusing strategies in digital markets and expanding competition rules to cover cases of abuses of economic dependence situations as well. A stricter competition policy against conglomerate power and data-based price discrimination, in contrast, is not (yet) at the heart of the discussion. From an economics perspective, the $9^{\text {th }}$ amendment of German competition law (with some minor exceptions) as well as the described proposals for a future $10^{\text {th }}$ amendment point into the right direction. Both the recent reform and the current modernization study contribute to making German competition policy fit for the digital age.

In contrast to Germany, European competition policy abstains from a digital-economy related reform of competition policy so far. However, this does not mean that elements of platform economics and - to a lesser extent - economics of personalized data are not taken into account in the treatment and handling of cases involving digital goods (see sections 4.1 and 4.2). Still, without being accompanied by institutional change, the necessary changes in competition policy in order to cope with the challenges of digitization may be more difficult to implement systematically (see section 4.3). For instance, the previously dominating paradigm that vertical and conglomerate arrangements and strategies are predominantly unlikely to cause consumer welfare damage is well-established - albeit mostly not in the codified rules of competition law but in guidelines, enforcement practices as well as in the minds of enforcers, lawyers and judges. Therefore, institutional change - be it of formal or informal institutions - is necessary to improve the protection of competition vis-à-vis new challenges from digitization. Adequate competition rules and policies safeguard the mostly beneficial economic development towards the digital economy by frustrating anticompetitive and welfare-decreasing strategies and arrangements without destroying the beneficial process and its inherent innovative power itself - something that non-antitrust based regulation is likely to cause. 
Therefore, we advocate a more explicit and proactive dealing with digitization-related challenges to competition policy. While we acknowledge that changing the law is virtually impossible and thanks to the general character of the relevant provisions also mostly not necessary (with the exception of amendments to merger regulation; see section 4.3), issuing guidelines for competition policy in digital markets and markets involving digital goods and/or personalized data may prove to be very helpful to implement a sound competition policy in the digital age. This may happen through an update of existing guidelines from the pre-digital age, complemented by new guidelines on abuse of market power and economic dependence (which would be helpful for other industries as well), or by publishing a guideline fully devoted to the digital economy.

Following the economically-sound parts of the German reform in departing from monetary volumes with respect to market delineation techniques as well as determination of market power and, in particular, complementing revenue-based review rules in merger control by transaction value stipulations and/or company value-based indicators represents a good starting point. Furthermore, considering the more fargoing reform discussion with its emphasis on re-invigorating competition policy enforcement against company strategies abusing market power as well as expanding abuse control to include cases of economic dependence would be beneficial for consumer welfare as well. The latter goes along with a less a priori lenient stance towards vertical integration and arrangements.

Beyond the topics already on the agenda in the (German) reform discussion, two more issues should be considered in our opinion. The first is the issue of conglomerate power, which is traditionally viewed to be a rather improbable case of antitrust concern. Mainly, the traditional reasoning focusing on the so-called deep pocket argument, emphasizing possible anticompetitive cross-market effects from financial power of conglomerates (cross-subsidization). Given the powerful positions of some of the digital players (like Google, Amazon, Facebook, Apple, etc.), the deep pocket concern may need to find renewed interest. Another more traditional reasoning is rooted in German ordoliberalism. This branch of economic thinking pays attention to the lobbyistic power of huge conglomerates, i.e. on the influence that big players gain on regulators and politicians. Currently, this may be more a concern for U.S. 
antitrust policy as the big players are all from the U.S. ${ }^{14}$ - although this may already look different with respect to the discussion around special tax deals as antitrust concerns (Hrushko 2017; European Commission 2017d). From the realms of more modern economics, effects of multi-market contact - especially among the biggest players - could imply a new type of antitrust concerns. Furthermore, market structure dynamics from conglomerate relations towards horizontal or vertical relations through innovative (platform) services and more inclusive platforms (e.g. walled garden strategies) may pose new challenges. Moreover, the modern economics of personalized data point to fact that a combination of personalized data from very different sources - so to say from conglomerate business activities - is potentially particularly attractive for companies and, at the same time, creates particularly excessive power over consumers. Data conglomerates may additionally control access to data along supply chains, creating scope for anticompetitive foreclosure strategies.

The second issue relates to data-based price discrimination. While this practice is only starting to become a feasible business strategy in - currently - merely very specific circumstances, its potential for decreasing consumer welfare is considerable (see section 2.2). Moreover, once consumers are confronted with data-based price discrimination regularly in their consumption activity, it has the potential to aggravating market skepticism ("unfair and exploitative practices by big capitalist firms") and driving people to favor regulatory alternatives. Thus, competition authorities should be critical towards data-based price discrimination strategies, in particular in combination with relative or absolute market power.

Altogether, digitization-related reforms of competition policy are beneficial to safeguard the predominantly welfare-increasing emergence of digital markets as well as business models and strategies. As the economic nature of this development favors an increase in (esp. relative) market power positions, competition policy needs to become less lenient and more active in combating the abuse of such positions as well as in preventing the emergence of (economically not necessary) absolute market power (for instance, by buying mavericks off the market). Next to the goal of an

\footnotetext{
14 However, the rising popularity of Chinese digital platforms should not be underestimated, also with a view to the pros and cons of contemporary Chinese competition policy.
} 
economics-based competition policy, a more political reasoning should also be considered. If antitrust policy does not "tame the tech titans", other regulation, which is less driven by free-market ideas, becomes more probable.

\section{References}

Acquisti, A. \& Varian, H. R. (2005), Conditioning Prices on Purchase History, in: Marketing Science, Vol. 24, pp. 267-381.

Acquisti, A.; Taylor, C. R. \& Wagman, L. (2016), The Economics of Privacy, in: Journal of Economic Literature, Vol. 54, pp. 442-492.

Affeldt, P.; Filistrucchi, L. \& Klein, T. J. (2013), Upward pricing pressure in two-sided markets, in: Economic Journal, Vol. 123, F505-F523.

Anderson, S. P. \& Gabszewicz, J. (2006), The Media and Advertising: A Tale of TwoSided Markets, in: Victor A. Ginsburg \& David Throsby (eds.): Handbook of the Economics of Art and Culture, Amsterdam, pp. 567-614.

Argentesi, E. \& Filistrucchi, L. (2007), Estimating Market Power in a Two-Sided Market: The Case of Newspapers, in: The Journal of Applied Econometrics, Vol. 22(7), pp. 1247-1266.

Armstrong, M. (2006), Competition in Two-Sided Markets, in: Rand Journal of Economics, Vol. 37, pp. 668-691.

Authority for Consumers and Markets (2018), History of ACM, URL: https://www.acm.nl/en/about-acm/our-organization/the-netherlands-authorityfor-consumers-and-markets (accessed September 19th, 2018).

Baye, M. R. \& Morgan, J. (2001), Information Gatekeepers on the Internet and the Competitiveness of Homogeneous Product Markets, in: American Economic Review, Vol. 91(3), pp. 454-474.

Bougette, P., Budzinski, O. \& Marty, F. (2017), Exploitative Abuse and Abuse of Economic Dependence, Ilmenau Economics Discussion Paper 111.

Brown, I. (2016), The economics of privacy, data protection and surveillance, in: Bauer, J. \& Latzer, M. (eds.), Handbook on the economics of the internet, Cheltenham: Edward Elgar, pp. 247-261. 
Budzinski, O. (2006), An Economic Perspective on the Jurisdictional Reform of the European Merger Control System, in: European Competition Journal, Vol. 2(1), pp. 119-140.

Budzinski, O. (2016), Wettbewerbsordnung online: Aktuelle Herausforderungen durch Marktplätze im Internet, in: ORDO, Vol. 67, pp. 385-409.

Budzinski, O. (2017), Wettbewerbsregeln für das Digitale Zeitalter? Die Ökonomik personalisierter Daten, Verbraucherschutz und die 9. GWB-Novelle, in: List Forum für Wirtschafts- und Finanzpolitik, Vol. 43(3), pp. 221-249.

Budzinski, O. \& Köhler, H. (2015), Is Amazon the next Google?, in: ORDO, Vol. 66, pp. 263-288.

Budzinski, O. \& Grusevaja, M. (2017), Die moderne Medienökonomik personalisierter Daten: der Fall Facebook, in: Wolfgang Seufert (ed.): Media Economics Revisited (Wie) verändert das Internet die Ökonomie der Medien?, Baden-Baden: Nomos, pp. 35-57.

Budzinski, O. \& Kuchinke, B.A. (2018), Modern Industrial Organization Theory of Media Markets and Competition Policy Implications, Ilmenau Economics Discussion Papers 115.

Budzinski, O. \& Stöhr, A. (2018), Die Ministererlaubnis als Element der deutschen Wettbewerbsordnung: eine theoretische und empirische Analyse, in: ORDO, Vol. 69 , forthcoming.

Budzinski, O., Noskova, V. \& Zhang, X. (2018), The Brave New World of Digital Personal Assistants: Benefits and Challenges from an Economic Perspective, Ilmenau Economics Discussion Papers.

Bundeskartellamt (2016), The Bundeskartellamt clarifies: Merger of long-distance bus operators not examined by the Bundeskartellamt, URL: https://www.bundeskartellamt.de/SharedDocs/Meldung/EN/Pressemitteilungen/2016/03_08_2016_Flixbus.html;jsessionid =DF5EDA3CCEE691020014D47CCF9177EB.1_cid387? $\mathrm{nn}=3591568$ (accessed September $30^{\text {th }}, 2018$ ). 
Bundeskartellamt (2018), Sector inquiries, URL: https://www.bundeskartellamt.de/EN/Economicsectors/Sectorinquiries/sectorinquiries_node.html;jsessionid =514DBFF9844794CD8BC4D2FCOBFCD1BF.2_cid387 (accessed June $12^{\text {th }}, 2018$ ).

Caillaud, B. \& Jullien, B. (2003), Chicken and Egg: Competition among Intermediation Service Providers, in: Rand Journal of Economics, Vol. 34, pp. 309-328.

Calvano, E.; Calzolari, G.; Denicolò, V. \& Pastorello, S. (2018), Algorithmic Pricing: What Implications for Competition Policy?, available at SSRN: https://ssrn.com/abstract $=3209781$.

Damme, E. van; Filistrucchi, L.; Geradin, D.; Keunen, S.; Kleine, T.; Michielsen, T. \& Wileur, J. (2010), Mergers in Two-Sided Markets - A Report to NMa, Netherlands Competition Authority, pp. 1 - 183.

Decker, C. (2017), Concepts of the Consumer in Competition, Regulatory, and Consumer Protection Policies, in: Journal of Competition Law \& Economics, Vol. 13(1), pp. 151-184.

Deutscher Bundestag (2017), Beschlussempfehlung und Bericht des Ausschusses für Wirtschaft und Energie, Drucksache 18/11446, Berlin.

Deutscher, E. (2017a), The role of personal data and privacy in merger analysis - a critical reassessment of the EU Commission's Facebook/WhatsApp decision, Firenze: European University Institute.

Deutscher, E. (2017b), How to Measure Privacy-Related Consumer Harm in Merger Analysis? A Critical Reassessment of the EU Commission's Merger Control in DataDriven Markets, Stockholm Faculty of Law Research Paper Series, No. 40.

Dinerstein, M., Einav, L., Levin, J. \& Sundaresan, N. (2018), Consumer Price Search and Platform Design in Internet Commerce, in: American Economic Review, Vol. 108(7), pp. 1820-1859.

European Commission (2014a), EU Competition Law: Merger legislation - Situation as at $1^{\text {st }}$ December 2014, Brussels.

European Commission (2014b), Regulation (EC) No 139/2004 - Merger Procedure, Article 6(1) (b) Non-Opposition, Date: 03/10/2014 Case No COMP/M.7217 - Facebook/WhatsApp, Brussels. 
European Commission (2017a), Commission Decision of 27.6.2017 relating to proceedings under Article 102 of the Treaty on the Functioning of the European Union and Article 54 of the Agreement on the European Economic Area, Case AT.39740 - Google Search (Shopping), Brussels.

European Commission (2017b), Antitrust - Commission fines Google €2.42 billion for abusing dominance as search engine by giving illegal advantage to own comparison shopping service - Factsheet, Brussels.

European Commission (2017c), Press Release, Mergers: Commission fines Facebook $€ 110$ million for providing misleading information about WhatsApp takeover, Brussels.

European Commission (2017d), Press Release, State aid: Commission refers Ireland to Court for failure to recover illegal tax benefits from Apple worth up to $€ 13$ billion, Brussels.

European Commission (2018), Press release - Mergers: Commission clears Apple's acquisition of Shazam, Brussels.

Evans, D. S. (2003), The Antitrust Economics of Multi-Sided Platform Markets, in: Yale Journal on Regulation, Vol. 20(2), pp. 325-381.

Evans, D. S. (2009), Two-Sided Market Definition, in: Market Definition in Antitrust: Theory and Case Studies, ABA Section of Antitrust Law.

Evans, D. S.; Hagiu, A. \& Schmalensee, R. (2004), A Survey of the Economic Role of Software Platforms in Computer-Based Industries, CES-IFO working paper.

Evans, D. S. \& Noel, M. D. (2005), Defining Antitrust Markets When Firms Operate Two-Sided Platforms, in: Columbia Business Law Review, Vol. 2005(3), pp. 667702.

Evans, D. S. \& Schmalensee, R. (2007), The industrial organization of markets with two-sided platforms, in: Competition Policy International, Vol. 3(1), pp. 151-179.

Evans, D. S. \& Noel, M. D. (2008), The Analysis of Mergers that involve Multisided Platform Businesses, in: Journal of Competition Law and Economics, Vol. 4(3), pp. 663-695.

Ezrachi, A. \& Stucke, M. (2016), Virtual Competition, in: Journal of European Competition Law \& Practice, Vol. 7(9), pp. 585-586. 
Ezrachi, A. \& Stucke, M. E. (2017), Artificial Intelligence \& Collusion: When Computers Inhibit Competition, in: University of Illinois Law Review, Vol. 69(5), pp. 17751809.

Ezrachi, A. \& Stucke, M. E. (2018), How Your Digital Helper May Undermine Your Welfare, and Our Democracy, in: Berkeley Technology Law Journal, Vol. 32(3), pp. 1239-1299.

Farrell, J. \& Klemperer, P. (2007), Coordination an Lock-in: Competition with Switching Costs and Network Effects, in: Mark Armstrong \& Robert H. Porter (eds.): Handbook of Industrial Organization, Vol. 3, Amsterdam: Elsevier, pp. 1967-2072.

Farrell, J. \& Saloner, G. (1985), Standardization, Compatibility, and Innovation, in: Rand Journal of Economics, Vol. 16, pp. 70-83.

Farrell, J. \& Shapiro, C. (2010), Antitrust Evaluation of Horizontal Mergers: An Economic Alternative to Market Definition, in: The B.E. Journal of Theoretical Economics, Vol. 10(1), 1-40.

Filistrucchi, L. (2008), A SSNIP Test for Two-Sided Markets: The Case of Media, NET Institute Working Paper, No. 2008-34.

Filistrucchi, L.; Geradin, D. \& van Damme, E. (2013a), Identifying Two-Sided Markets, in: World Competition, Vol. 36(1), pp. 33-59.

Filistrucchi, L.; Geradin, D.; van Damme, E. \& Affeldt, P. (2013b), Market Definition in Two-Sided Markets: Theory and Practice, in: Journal of Competition Law and Economics, Vol. 10, pp. 293-339.

Gal, M. (2018), Algorithmic Challenges to Autonomous Choice, in: Michigan Telecommunications and Technology Law Review, Vol. 24, forthcoming, discussion paper available at SSRN: http://dx.doi.org/10.2139/ssrn.2971456.

Haucap, J. \& Heimeshoff, U. (2014), Google, Facebook, Amazon, eBay: is the internet driving competition or market monopolization?, in: International Economics and Economic Policy, Vol. 11(1), pp. 49-61.

Haucap, J. \& Stühmeier, T. (2016), Competition and antitrust in internet markets, in: Bauer, J. \& Latzer, M. (eds.): Handbook on the economics of the Internet, Cheltenham: Edward Elgar, pp. 183-210.

Heidhues, P. \& Köszegi, B. (2017), Naivete-Based Discrimination, in: The Quarterly Journal of Economics, Vol. 132(2), pp. 1019-1054. 
Heidhues, P.; Köszegi, B. \& Murooka, T. (2017), Inferior Products and Profitable Deception, in: Review of Economic Studies, Vol. 84, pp. 323-356.

Hermalin, B. E. \& Katz, M. L. (2006), Privacy, Property Rights and Efficiency: The Economics of Privacy as Secrecy, in: Quantitative Marketing and Economics, Vol. 4, pp. 209-239.

Hrushko, N. (2017), Tax in the World of Antitrust Enforcement: European Commission's State Aid Investigations into EU Member States' Tax Rulings, in: Brooklyn Journal of International Law, Vol. 43(1), pp. 327-360.

Kaplow, L. (2011), Market Definition and the Merger Guidelines, in: Review of Industrial Organization, Vol. 39(1-2), pp. 107-125.

Kaplow, L. (2015), Market Definition, Market Power, in: International Journal of Industrial Organization, Vol. 43, pp. 148-161.

Katz, M. L. \& Shapiro, C. (1985), Network Externalities, Competition, and Compatibility, in: American Economic Review, Vol. 75, pp. 424-440.

Kerber, W. (2016), Digital Markets, Data, and Privacy: Competition Law, Consumer Law and Data Protection, in: Journal of Intellectual Property Law \& Practice, Vol. 11(11), pp. 856-866.

Kerber, W. \& Frank, S. (2017), Data Governance Regimes in the Digital Economy: The Example of Connected Cars, available at SSRN: https://ssrn.com/abstract $=3064794$.

Kerber, W. \& Schweitzer, H. (2017), Interoperability in the Digital Economy, in: Journal of Intellectual Property, Information Technology and Electronic Commerce Law, Vol. 8(1), pp. 39-58.

Lim, Y. (2017), Tech Wars: Return of the Conglomerate - Throwback or Dawn of a New Series for Competition in the Digital Era?, available at SSRN: https://ssrn.com/abstract $=3051560$.

Obar, J. \& Oeldorf-Hirsch, A. (2018), The Biggest Lie on the Internet: Ignoring the Privacy Policies and Terms of Service Policies of Social Networking Services, in: Information, Communication \& Society, https://doi.org/10.1080/1369118X.2018. 1486870.

OECD (2018), Consumer Protection Enforcement in a Global Digital Marketplace, OECD Digital Economy Papers, No. 266. 
Petit, N. (2016), Technology Giants, the Moligopoly Hypothesis and Holistic Competition: A Primer, available at SSRN: https://ssrn.com/abstract $=2856502$.

Podszun, R. (2018), How to Reform the Law on Abusive Practices: The Study that Will Serve as a Basis for Reform in Germany (and Europe?), CPI's Europe Column September 2018.

Posner, R. A. (1981), The Economics of Privacy, in: The American Economic Review, Vol. 71(2), pp. 405-409.

Rochet, J.-C. \& Tirole, J. (2002), Cooperation among Competitors: The Economics of Payment Card Associations, in: Rand Journal of Economics, Vol. 33, pp. 549-570.

Rochet, J.-C. \& Tirole, J. (2003), Platform competition in two-sided markets, in: Journal of the European Economic Association, Vol. 1(4), pp. 990-1029.

Rochet, J.-C. \& Tirole, J. (2006), Two-Sided Markets: A Progress Report, in: Rand Journal of Economics, Vol. 37, pp. 645-667.

Salcedo, B. (2015), Pricing Algorithms and Tacit Collusion. Manuscript. Pennsylvania State University.

Salop, S. C. (2018), Invigorating Vertical Merger Enforcement, in: The Yale Law Journal, Vol. 127, pp. 1962-1994.

Schwalbe, U. (2017), Stellungnahme zur Anhörung zu den Themen Digitalisierung, Presse- und Medienkooperationen in der 9. GWB-Novelle, Ausschussdrucksache 18(9)1095, Berlin.

Schwalbe, U. (2018), Algorithms, Machine Learning, and Collusion, Discussion Paper, URL: https://www.uni-hohenheim.de/organisation/publikation/algorithmus-machine-learning-and-collusion (accessed August 07 ${ }^{\text {th }}, 2018$ ).

Schweitzer, H., Haucap, J., Kerber, W. \& Welker, R. (2018), Modernisierung der Missbrauchsaufsicht für marktmächtige Unternehmen, Endbericht, Düsseldorf: DICE Consult.

Shy, O. \& Stenbacka, R. (2016), Customer Privacy and Competition, in: Journal of Economics and Management Strategy, Vol. 25, pp. 539-562.

Stigler, G. J. (1980), An Introduction to Privacy in Economics and Politics, in: The Journal of Legal Studies, Vol. 9(4), pp. 623-644.

Taylor, C. R. (2004), Consumer Privacy and the Market for Customer Information, in: RAND Journal of Economics, Vol. 35(4), pp. 631-651. 
Tucker, C. E. (2012), The economics of advertising and pricing, in: International Journal of Industrial Organization, Vol. 30(3), pp. 326-329.

Varian, H. (1997), Economic Aspects of Personal Privacy, in: William M. Daley \& Larry Irving (eds.): Privacy and Self-Regulation in the Information Age, Washington, D.C. 


\section{Diskussionspapiere aus dem Institut für Volkswirtschaftslehre der Technischen Universität IImenau}

Nr. 69 Budzinski, Oliver: Empirische Ex-Post Evaluation von wettbewerbspolitischen Entscheidungen: Methodische Anmerkungen, Januar 2012.

Nr. 70 Budzinski, Oliver: The Institutional Framework for Doing Sports Business: Principles of EU Competition Policy in Sports Markets, January 2012.

Nr. 71 Budzinski, Oliver; Monostori, Katalin: Intellectual Property Rights and the WTO, April 2012.

Nr. 72 Budzinski, Oliver: International Antitrust Institutions, Juli 2012.

Nr. 73 Lindstädt, Nadine; Budzinski, Oliver: Newspaper vs. Online Advertising - Is There a Niche for Newspapers in Modern Advertising Markets?

Nr. 74 Budzinski, Oliver; Lindstädt, Nadine: Newspaper and Internet Display Advertising - Co-Existence or Substitution?, Juli 2012b.

Nr. 75 Budzinski, Oliver: Impact Evaluation of Merger Control Decisions, August 2012.

Nr. 76 Budzinski, Oliver; Kuchinke, Björn A.: Deal or No Deal? Consensual Arrangements as an Instrument of European Competition Policy, August 2012.

Nr. 77 Pawlowski, Tim, Budzinski, Oliver: The (Monetary) Value of Competitive Balance for Sport Consumers, Oktober 2012.

Nr. 78 Budzinski, Oliver: Würde eine unabhängige europäische Wettbewerbsbehörde eine bessere Wettbewerbspolitik machen?, November 2012.

Nr. 79 Budzinski, Oliver; Monostori, Katalin; Pannicke, Julia: Der Schutz geistiger Eigentumsrechte in der Welthandelsorganisation - Urheberrechte im TRIPS Abkommen und die digitale Herausforderung, November 2012.

Nr. 80 Beigi, Maryam H. A.; Budzinski, Oliver: On the Use of Event Studies to Evaluate Economic Policy Decisions: A Note of Caution, Dezember 2012.

Nr. 81 Budzinski, Oliver; Beigi, Maryam H. A.: Competition Policy Agendas for Industrializing Countries, Mai 2013. 
Nr. 82 Budzinski, Oliver; Müller, Anika: Finanzregulierung und internationale Wettbewerbsfähigkeit: der Fall Deutsche Bundesliga, Mai 2013.

Nr. 83 Doose, Anna Maria: Methods for Calculating Cartel Damages: A Survey, Dezember 2013.

Nr. 84 Pawlowski, Tim; Budzinski, Oliver: Competitive Balance and Attention Level Effects: Theore-tical Considerations and Preliminary Evidence, März 2014.

Nr. 85 Budzinski, Oliver: The Competition Economics of Financial Fair Play, März 2014.

Nr. 86 Budzinski, Oliver; Szymanski, Stefan: Are Restrictions of Competition by Sports Associations Horizontal or Vertical in Nature?, März, 2014.

Nr. 87 Budzinski, Oliver: Lead Jurisdiction Concepts Towards Rationalizing Multiple Competition Policy Enforcement Procedures, Juni 2014.

Nr. 88 Budzinski, Oliver: Bemerkungen zur ökonomischen Analyse von Sicherheit, August 2014.

Nr. 89 Budzinski, Oliver; Pawlowski, Tim: The Behavioural Economics of Competitive Balance: Implications for League Policy and Championship Management, September 2014.

Nr. 90 Grebel, Thomas; Stuetzer, Michael: Assessment of the Environmental Performance of European Countries over Time: Addressing the Role of Carbon, September 2014.

Nr. 91 Emam, Sherief; Grebel, Thomas: Rising Energy Prices and Advances in Renewable Energy Technologies, July 2014.

Nr. 92 Budzinski, Oliver; Pannicke, Julia: Culturally-Biased Voting in the Eurovision Song Contest: Do National Contests Differ?, December 2014.

Nr. 93 Budzinski, Oliver; Eckert, Sandra: Wettbewerb und Regulierung, März 2015.

Nr. 94 Budzinski, Oliver; Feddersen, Arne: Grundlagen der Sportnachfrage: Theorie und Empirie der Einflussfaktoren auf die Zuschauernachfrage, Mai 2015.

Nr. 95 Pannicke, Julia: Abstimmungsverhalten im Bundesvision Song Contest: Regionale Nähe versus Qualität der Musik, Oktober 2015.

Nr. 96 Budzinski, Oliver; Kretschmer, Jürgen-Peter: Unprofitable Horizontal Mergers, External Effects, and Welfare, October 2015. 
Nr. 97 Budzinski, Oliver; Köhler, Karoline Henrike: Is Amazon The Next Google?, October 2015.

Nr. 98 Kaimann, Daniel; Pannicke, Julia: Movie success in a genre specific contest: Evidence from the US film industry, December 2015.

Nr. 99 Pannicke, Julia: Media Bias in Women's Magazines: Do Advertisements Influence Editorial Content?, December 2015.

Nr. 100 Neute, Nadine; Budzinski, Oliver: Ökonomische Anmerkungen zur aktuellen Netzneutralitätspolitik in den USA, Mai 2016.

Nr. 101 Budzinski, Oliver; Pannicke, Julia: Do Preferences for Pop Music Converge across Countries? - Empirical Evidence from the Eurovision Song Contest, Juni 2016.

Nr. 102 Budzinski, Oliver; Müller-Kock, Anika: Market Power and Media Revenue Allocation in Professonal Sports: The Case of Formula One, Juni 2016.

Nr. 103 Budzinski, Oliver: Aktuelle Herausforderungen der Wettbewerbspolitik durch Marktplätze im Internet, September 2016.

Nr. 104 Budzinski, Oliver: Sind Wettbewerbe im Profisport Rattenrennen?, Februar 2017.

Nr. 105 Budzinski, Oliver; Schneider, Sonja: Smart Fitness: Ökonomische Effekte einer Digitalisierung der Selbstvermessung, März 2017.

Nr. 106 Budzinski, Oliver; Pannicke, Julia: Does Popularity Matter in a TV Song Competition? Evidence from a National Music Contest, April 2017.

Nr. 107 Budzinski, Oliver; Grusevaja, Marina:Die Medienökonomik personalisierter Daten und der Facebook-Fall, April 2017.

Nr. 108 Budzinski, Oliver: Wettbewerbsregeln für das Digitale Zeialter - Die Ökonomik personalisierter Daten, Verbraucherschutz und die 9.GWB-Novelle, August 2017.

Nr. 109 Budzinski, Oliver: Four Cases in Sports Competition Policy: Baseball, Judo, Football, and Motor Racing, September 2017.

Nr. 110 Budzinski, Oliver: Market-internal Financial Regulation in Sports as an Anticompetitive Institution, October 2017.

Nr. 111 Bougette, Patrice; Budzinski, Oliver; Marty, Frédéric: EXPLOITATIVE ABUSE AND ABUSE OF ECONOMIC DEPENDENCE: WHAT CAN WE LEARN FROM THE INDUSTRIAL ORGANIZATION APPROACH?, December 2017. 
Nr. 112 Budzinski, Oliver; Gaenssle, Sophia: The Economics of Social Media Stars: An Empirical Investigation of Stardom, Popularity, and Success on YouTube, Januar 2018.

Nr. 113 Gaenssle, Sophia; Budzinski, Oliver; Astakhova Daria: Conquering the Box Office: Factors, influencing Success of International Movies in Russia, Mai 2018.

Nr. 114 Budzinski, Oliver; Stöhr, Annika: Die Ministererlaubnis als Element der deutschen Wettbewerbsordnung: eine theoretische und empirische Analyse, Juli 2018.

Nr. 115 Budzinski, Oliver; Kuchinke, Björn A.: Modern Industrial Organization Theory of Media Markets and Competition Policy Implications, September 2018.

Nr. 116 Budzinski, Oliver; Lindstädt-Dreusicke, Nadine: The New Media Economics of Video-on-Demand Markets: Lessons for Competition Policy, Oktober 2018. 